\title{
Why Did Cantillon Change the Meaning of Entrepreneurship?
}

\author{
Mark Thorton ${ }^{\mathrm{I}}$ \\ Mises Institute, Alburn, AL, United States
}

\begin{abstract}
In breaking with the policy regime of mercantilism, Richard Cantillon put forth a manuscript in 1730, wherein he produced the first treatise of economic theory. Key to this development was his new theory of entrepreneurship which allowed him to construct economic theories and concepts. Recent research has shown that he did not coin the term, but rather radically changed the meaning of an existing term, to its near opposite. This paper explores why he changed the meaning of the entrepreneur. The speculative answer is both theoretical and based on his life experience.
\end{abstract}

Keywords: Richard Cantillon, Entrepreneurship, history, History of Economic Thought. 


\section{Por que Cantillon mudou o significado de empreendedorismo?}

Resumo: Ao romper com o regime político do Mercantilismo, Richard Cantillon lançou um manuscrito em 1730 que continha o primeiro tratado de teoria econômica. Uma de suas peças centrais é sua nova teoria do empreendedorismo, que lhe permitiu construir teorias e conceitos econômicos. Pesquisas recentes mostram que ele não cunhou o termo, mas que inverteu radicalmente o significado do termo existente. A resposta especulativa é tanto teórica como baseada em sua experiência de vida.

Palavras-chave: Richard Cantillon, Empreendedorismo, história, história do pensamento econômico (HPE).

\section{¿Por qué Cantillon cambió el significado del emprendimiento?}

Resumen: Al romper con el régimen político del mercantilismo, Richard Cantillon presentó un manuscrito en 1730, en el que produjo el primer tratado de teoría económica. La clave de este desarrollo fue su nueva teoría del emprendimiento, que le permitió construir teorías y conceptos económicos. Investigaciones recientes han demostrado que no acunó el término, sino que cambió radicalmente el significado de un término existente, a su casi opuesto. Este artículo explora por qué cambió el significado del emprendedor. La respuesta especulativa es tanto teórica como basada en su experiencia de vida.

Palavras-clave: Richard Cantillon, emprendimiento, historia, historia del pensamiento económico. 


\section{Introduction}

Richard Cantillon is now acknowledged as the first economic theorist and rightly deserves to be known as the father of economics. William Stanley Jevons, who is credited for rediscovering Cantillon and one of the co-founders of the Marginal Revolution called the Essai "a systematic and connected treatise, going over in a concise manner nearly the whole field of economics... It is thus the first treatise on economics." Joseph Schumpeter called the Essai "the first systematic penetration of the field of economics. It bears the stamp of a scientific spirit." Joseph J. Spengler famously dubbed Cantillon the "first of the moderns." F.A. Hayek described Cantillon as "the first person to succeed in penetrating and surveying nearly the entire range of what today we call economics." Murray N. Rothbard named Cantillon "the founding father of modern economics." Thornton (1998) provides a full description of Cantillon as the originator of economic theory.

Despite all this high praise from the leaders of the field of the history of economic thought, many of his views have remained unclear until recent years. For example, his theory of value has been wrongly interpreted as an objective, i.e. intrinsic, theory of value, or land or labor only theory of value, or even that he was a surplus value theorist. In contrast, Thornton (1998; 2009a) has shown that he actually had a very modern subjectivist theory of value.

Also, he has long been characterized as a mercantilist thinker based on the time in which he wrote and some mischaracterizations of his writings. Thornton (2007b; 2007c; 2009b) has shown that instead he had very strong anti-mercantilist views, especially criticizing the core mercantilist belief that money was wealth, and other misinterpretations failed because they were ahistorical. In fact, Ekelund, Hébert and Thornton (2019) show that Cantillon was the key theorist for the largely unrecognized French anti-mercantilist tradition, which spanned period of the late $17^{\text {th }}$ century to the French Revolution.

Many of his foundational contributions have also gone unnoticed until recently. In connection with the confusion over his value theory, Thornton (2009a) has shown that his term intrinsic value is actually synonymous with the modern term of opportunity cost and he uses it to show the opportunity cost of an apprenticeship, which is parallel to the modern textbook example of the opportunity cost of going to college. He also uses it to explain that the opportunity cost of property improvements is not the same as market value and he even uses it to defend the charging of high rates of interest in his famous defense of usury. Discovering and understanding this concept is no doubt important for understanding his theory of entrepreneurship.

Even more pertinent here, Thornton (2009a) shows that Adam Smith used Cantillon's Essai as a basis for his phrase the "invisible hand," the veritable slogan of entrepreneurship. We know that Smith had access to Cantillon's Essai and that he referenced Cantillon in the Wealth of Nations. In his Theory of Moral Sentiments (1759), Smith described that nature produces results which seem to be divine. In the case of massive inequality of land ownership that characterized his world, he showed that the landowner consumes only a tiny fraction of production and that he must feed and support all those who work for him, which makes production possible. In the Wealth of Nations (1776), he used the phrase to indicate that self interest leads people to 
unintentionally produce the most economic value for the general interest. Both of these uses of the phrase by Smith are tied to Cantillon's model of the isolated estate ${ }^{1}$.

Cantillon described entrepreneurship as pervasive and he casted the entrepreneur with a pivotal role in the economy. Using a sample of models from Cantillon's Essai, Brown and Thornton (2013) provide evidence that his theory of entrepreneurship was the fundamental tool by which he constructed economic theory. Absent his theory of entrepreneurship all his theoretical constructions fail. One example of this is the price-specie flow mechanism where gold, i.e., money, flows internationally from nations that have relatively high amounts of money to nations that have relatively low amounts money. What generates this flow is the purposeful behavior of entrepreneurs and consumers who take independent self- interested actions based on the purchasing power of money and local and foreign prices to generate a powerful regulator of international monetary equilibrium².

Thornton (2019) shows that Cantillon actually changed the existing meaning of entrepreneurship and his "students" then disseminated that new definition to the world at large.

The word entrepreneur originally meant someone who is active, risky, and even violent. In the sixteenth and seventeenth centuries it was used to denote a contractor who built large structures and fortifications for the government or provided supplies to the military for a fee, but who often had uncertain costs. In contrast, Cantillon defined the entrepreneur as someone buying goods or materials and labor resources to be sold as goods in the future for uncertain prices. His definition has since become part of the common usage of the term. As two of the leading scholars on the subject conclude:

Cantillon's work is a watershed in the development of entrepreneurial theory precisely because by the time we get to his treatment of the subject, emphasis is being placed squarely on the purely commercial aspects of "getting things done" in the market. (HEBERT; LINK, 1982, p. 13)

The question here is: why did Cantillon change the meaning of the term entrepreneur? Any answer to that question is necessarily speculative. However, the answer given here is highly plausible. The answer here is twofold. On the one hand, it is theoretical in that the entrepreneur is dependable in certain ways, such as profit maximization and uncertainly bearing. The entrepreneur is self-regulated by self-interest, the system of profit and loss, and market competition. On the other hand, it is based on his career experience. He had extensive work experience as both types of entrepreneurs: market entrepreneurs and government contractors.

\section{The Entrepreneur is Essential to Economic Theory}

In an age when entrepreneurship is not even a topic in graduate-level economics education, it might seem strange to argue that that entrepreneurship theory is essential for economic theory. Despite this, absent entrepreneurship, the theory and models of economics do not function

\footnotetext{
${ }^{1}$ See Cantillon (1755) Part 1, Chapter 14.

${ }^{2}$ See Murphy (1986) for his discussion of the discovery of the price specie flow mechanism, previously attributed to David Hume.
} 
and the economy is driven down to primitive levels. In a world devoid of entrepreneurship; theory, models, hypotheses, and empirical testing become problematic and unlikely to yield any interesting results. So, this is a previously unrecognized key juncture of the origin of economics because Cantillon's new definition can be viewed as the necessary ingredient for the creation of economics theory.

Cantillon redefined the work entrepreneur to nearly its opposite. Most people would not consider redefining a word or concept. Even if the average person did try, there would be little chance that the new meaning would be accepted and used by the general population. In the few successful cases of usurping the meaning of a term, most of the important ones are done for nefarious reasons and propaganda purposes.

One example is the term "liberal" which was appropriated by the progressives when their first propaganda effort failed to hide the fact that they were actually fascists, racists, and eugenicists, especially after the experience of Hitler and his murderous national socialist regime. $^{3}$

The second important example is the use of the term "capitalism" by Marxists. Here, the problems of the real world such as income and wealth inequality, alienation of labor, slavery, war and "phishing for phools"4 are attributed to the "free market," aka capitalism. In reality, these problems are either partly of wholly natural, but when especially painful, are actually caused by government intervention into the free market.

In contrast to these ideological motivations, Cantillon redefined the term entrepreneurship for scientific purposes, or so that was the result. He was looking for automatic nature-given forces based on human nature that guide and regulate the economy. Hence, the title of his manuscript, Essai sur la Nature du Commerce en Géneral, which can be translated as An Essay on Economic Theory.

Cantillon was looking for the general forces which made the economy well regulated. He may well have been inspired by Isaac Newton who published his path-breaking book on gravity in 1687, with new editions in 1713 and 1726. It is noteworthy, that while economists and other philosophers did not integrate the advances of the physical sciences until much later, Cantillon was familiar with Newton's and Edmund Halley's work, and many other thinkers of the era, and he said that he actually communicated and debated the scientist, mathematician and alchemist, ${ }^{5}$ Sir Isaac Newton, when Newton was Warden of the Royal Mint.

\footnotetext{
${ }^{3}$ There are many different understandings of the word liberal. See Haitz (1955). Today's liberals in the US are quite different and many ways the opposite as understood in the rest of the world. After Progressivism's great success in the 1920s, the movement declined after the failure of Alcohol Prohibition, and especially after WWII and the experience of Fascism and Nazism. Leonard (2016) shows that progressive share many of the goals and policies of the fascists and Nazis, including eugenics. In the modern context, American liberal are transitioning from "left wing," to Progressivism in terms of controlling society, except not a white male society, but rather an anti-white male society.

${ }^{4}$ See Thornton (2016) for a description of this concept and a full critique of it application to the free market.

${ }^{5}$ See Cantillon $(1755$, p. 14). Henry Higgs, who did the first English translation and William Stanley Jevons who rediscovered Cantillon in the late $19^{\text {th }}$ century, did a great deal of investigation into Cantillon's life and are quite convinced of this speculation concerning the meeting of the two men.
} 
In this speculation, Cantillon's self-interested entrepreneur in the economy is the equivalent of Newton's role of gravity in the regulation of the physical universe.

Cantillon's entrepreneur is well regulated by the forces of self-interest, competition, the system of profit and loss and other market forces. In Cantillon's model of the isolated estate, the estate owner leases his various farms to his farm managers, who then become entrepreneurs who now want to maximize profits rather than just managing the owner's decisions. They decide what to plant on the farm in order to sell goods in markets for unknown future prices. ${ }^{6}$

One factor that makes it relatively easy for the market to be well regulated is that typically Cantillon's entrepreneurs engage in a market activity on an ongoing basis in competition with many others. For example, a family has been engaged in making wine for many decades. They are familiar with their cost function, various recipes to improve their products, local demand conditions, and export opportunities. Their customers are familiar with their products and some of their competitors' as well as past prices. All this information minimizes trickery and scams and encourages entrepreneurs to create "good will".7

Some will profit from unexpectedly high prices for their products and others will suffer loses as a result of unexpectedly low prices for their products. Those profit and loss signals will impact how the farmers act in the future. Consistent losses will drive some of the farmers into bankruptcy while consistent profits might allow some farmers to become owners and independent. This model of the isolated estate provides a sketch of the transition from feudalism, which is centrally directed by the estate owner, to capitalism where the economy needs no central director in order to function. Earlier writers, such as Vauban and Boisguilbert, understood the self-regulating nature of the market, but here Cantillon demonstrates it, in theory, for the first time.

One possible reason that Cantillon selected the market entrepreneur as the basis for his study of commerce is straightforward. It is clear that uncertainty bearing by entrepreneurs in the market was part and parcel of the market economy's capacity for self-regulation. If you did not successfully serve your customers, then you would go out of business and be replaced. This self-regulation provided a basis for studying the nature of commerce in general.

While the government contractor type of entrepreneur was also a risk bearer, it was risk of a different sort. The government contractor is not well regulated, but difficult to regulate. The contractor will typically try to minimize their costs by using inferior materials, use inadequate amounts of materials, and change the mix of materials. The contractor might also use more unskilled labor and less skilled labor resulting in an inferior product. Government contractors are also notorious for not completely projects on time.

Plus, government contractors are typically used for special or unique projects, such as the construction of fortresses in a certain location. These projects were not integral to commerce, nor

\footnotetext{
${ }^{6}$ See Part 1, Chapter 14 in which he discussed his model of the isolated estate (p. 66). This essentially shows the evolution of feudalism, with large estate owners, into capitalism, with entrepreneurs.

${ }^{7}$ The advantage that a business has acquired through its brands and its good reputation which expands its consumer base and increases it customers' loyalty. In contrast, Adam Smith felt that the human conscience was the potent force that controlled behavior.
} 
were they integrated into the system of commerce. Hence his choice of dropping the traditional meanings of government contractor of adopting the new meaning is clearly justified. As we will see, Cantillon was intimately familiar with both types of entrepreneurs, the regularity of market entrepreneurs and the chicanery of government contractors ${ }^{8}$.

\section{Cantillon's Life as both Types of Entrepreneur ${ }^{9}$}

Cantillon's career experience made him acutely aware of the stark differences between a government contractor and a private-sector business owner. Contractors who work for the government have an incentive to cut costs and quality and in some situations to "pad" their expenses in order to increase profits when working on a "cost-plus" contract. Cantillon's experience working in the British Paymaster General's office and his work for John Law and the Mississippi Company are examples of his work as a government contractor and they both turned out to be the biggest scams that occurred during Cantillon's lifetime. In contrast, his ownership of a bank made him well aware that business entrepreneurs faced different incentives and constraints. As a lender, Cantillon would also be exposed to the experience of his cliententrepreneurs functioning in a variety of markets. He considered bankers to be entrepreneurs to the extent that they shared the entrepreneur's uncertainty. His career experience therefore provides the distinctive features of both types of entrepreneurs.

Knowledge of Cantillon's life and his Essai had long been little known and obscured. However, thanks to the remarkable biography by Antoin Murphy (1986) there is now a great deal of detailed knowledge of Cantillon's remarkable life, noteworthy career, and economic contributions. The following section will be based heavily on material from that book so it is not original research, but merely a speculative application.

His life can be divided into three careers. His first major career was as an accountant and purchasing agent for an operation that supplied money and provisions to British troops in Spain during the War of Spanish Succession (1701-14). His second career was as a private sector banker. His third career was with John Law as a government contractor in the publicprivate partnership known as the Mississippi Company.

The division of Cantillon's life into three careers allows us to provide evidence that suggests why he turned the meaning of the term entrepreneur upside down. The first and third careers can be classified under the older definition of entrepreneur as government contractor, while his second career as a banker can be classified as an entrepreneur in line with his new definition. Murphy (1986) has shown that many of Cantillon's life experiences may have had an impact on the Essai. We believe there is evidence to support the speculation that his professional experiences influenced his new definition of entrepreneurship ${ }^{\mathbf{1 0}}$.

\footnotetext{
${ }^{8}$ On the problems of government contracting see Blidor (1929). For a more modern example, see Johnson and Libecap (1982) or just look around at the modern public works projects with the almost predictable delays, cost overruns, and faulty construction.

${ }^{9}$ All the details of Cantillon's life and careers can be found in Murphy (1986).

${ }^{10}$ Murphy (1986) concludes that Cantillon must have been writing the Essai around 1730 well after his careers were over and he was essentially in retirement.
} 


\section{Cantillon and the War Profiteer}

Cantillon came from a family of Irish Catholic gentlemen farmers who were downgraded to tenant farmers when the regime of Oliver Cromwell took their property. Cantillon's great uncle, Sir Daniel Arthur, a prominent Jacobite and banker, likely arranged for Cantillon to work for the British paymaster general, James Brydges. Cantillon became a clerk in the office of the assistant paymaster in Spain. Their operations involved procuring and delivering provisions to British troops in Spain during the War of the Spanish Succession.

Banks such as Daniel Arthur's would receive a fee for redeeming the banknotes of the paymaster general and other clients in foreign countries. The agent of the paymaster would then use these funds to purchase provisions for the troops, take his own fee, and send the receipts for these purchases back to the main office. Brydges carried on an extensive correspondence with Cantillon, but according to Murphy (1986, p. 29), Brydges "was more concerned with his unofficial private market transactions than with his official public function as Paymaster General". In his eight years as paymaster general, Brydges is reputed to have amassed a fortune of more than $£ 600,000$, making him one of the most successful war profiteers of the time ${ }^{11}$.

Murphy (1986, p. 34-39) shows that Brydges made money for himself in all aspects of the job of paymaster general. Cantillon was talented at negotiations and bookkeeping. At one point, he suggested that they keep two sets of books, a suggestion which Brydges happily agreed "because that will tend to put in better order the general [accounts] that we will be obliged from time to time to produce for the Treasury" (1986, p. 37). It would thus seem that Cantillon was first making purchases of provisions for Brydges's personal account and then reselling them to the paymaster general's official account at much higher prices. If resources were insufficient, the troops would go without provisions until the British Treasury allocated more money.

Cantillon's job working for the paymaster general's office is an example of the entrepreneur as government contractor. In theory, the government contractor received a set amount of revenue while expenses were uncertain and the contractor was free to cut corners or pad expenses with cost plus-pricing schemes., or in Cantillon's case of keeping a double set of books. In theory, both types of entrepreneur bore a risk: the government contractor risked input prices rising while the market entrepreneur risked product prices falling. However, in reality the risk associated with being a government-contract entrepreneur was far different from that of the market entrepreneur.

With the Paymaster General's office, there was virtually no market-related risk, as it was on a "cost-plus" arrangement. The only real risk was getting caught defrauding the government and being punished. That is probably why Brydges eagerly hired a young Irishman who had no allegiance to the British government, and probably a good deal of animosity.

When contractors work for government, they are often working on projects that are unusual or unique to government. Hoselitz (1951) points out that the price of the contract became fixed and profit or loss was based on the entrepreneurs' (as government contractors)

${ }^{11}$ According to EH.NET the estimate of his wealth would be worth about $\$ 7.5$ billion. 
abilities to "control" costs. It also means that market data about costs are often difficult to obtain. For example, government inspectors know the price of apples but they do not know the price of apples in a war zone far from home. This information asymmetry can put government contractors in a strategic position. How much does it cost to go to the moon, build the best tank in the world, or clean up a pollution site?

Government contractors reduce or eliminate their risk by padding expenses, entering into cost-plus contracts, and skimping on materials and workmanship. For example, graft and corruption are endemic in military procurement, as Gupta, de Mello and Sharan (2001) have reconfirmed, for example, that higher levels of military spending and weapons procurement are associated with more corruption and lower quality of governance. Bélidor (1729) discusses at great length how government contractors try to cheat the government by, among other things, using inferior materials and insufficiently trained workers to keep cost low. He also discussed some remedial tactics to reduce corruption and waste.

Brydges's operations provided several opportunities for corrupt practices and he was basically guaranteed to make very large profits. The first step was to transfer money from London to Spain, which was done with the use of banknotes that were transmitted and redeemed by bankers in Spain. Presumably, Cantillon and his family members would be all too willing to participate in a plot against the British government and would also be reliably secretive about it. The second step was to spend the money procuring goods for the troops in Spain. It seems that Cantillon first used the money to purchase the goods for Brydges's personal account, then marked up their prices, before reselling the goods to the official government account of the paymaster general's office (MURPHY, 1986). This was a type of racketeering carefully concealed with Cantillon's two sets of books. It provided Brydges with additional profits on top of the normal amount he received for his services. In addition to the graft and racketeering, Brydges also used his office to secure insider information regarding the war in order to better position his own investments at home.

Between 1709 and 1713, Brydges was paid thirteen million pounds for the overseas military. If he was given 1 percent of this money for his services, another 1.5 percent graft from foreign exchange transactions, and just 2.5 percent of additional markup on purchases, it would be sufficient to account for the estimated $£ 600,000$ to $£ 700,000$ he acquired through corrupt activities at the paymaster general's office. Brydges delay in disbursing the money meant that Brydges had more money to invest on his own. Although officially a part of the government, the British paymaster general's office was in effect a type of government contractor. This experience must have had a big impact on Cantillon's thinking and very easily could have served as a model for his understanding of the government-contractor entrepreneur.

\section{Cantillon the Banker}

Cantillon's career in banking could have played an important role in developing his theory of entrepreneurship. He considered bankers and most of their customers to be entrepreneurs. Their primary business, according to Cantillon, was to take deposits and to issue and redeem banknotes for a fee. Banknotes can be redeemed either by the "issuing bank" or a "corresponding bank" in another city. The Cantillon family had a network of corresponding banks across Europe to redeem each other's banknotes. At first, this might appear to be like the government 
contractor who works for a fixed fee, but the bank risks losing both capital and fee income if the money is lost or stolen in transit. ${ }^{12}$

Bankers can also make loans, as do investors, wholesalers, and so forth. Throughout history, the reputation of bankers has been tarnished at best. This was particularly true in Cantillon's time because making loans was restricted due to usury laws. In fact, according to Murphy (1986) criminal charges of usury against Cantillon may have motivated him to write the Essai, as legal briefs submitted by his lawyers offer similar arguments to the arguments Cantillon's made in his Essai.

Cantillon's major argument is that all sorts of people make loans, in effect, to a wide range of entrepreneurs and charge high de facto interest rates on the loans. For example, a brewer might deliver kegs of beer to a pub in return for payment at a later date with an effective annualized interest rate of 500 percent. In these situations, the lender takes great risk and makes no extraordinary profits because the default rate is high. Furthermore, Cantillon (2010, p. 173) notes that the consumer who ultimately pays for these high rates "is satisfied with this convenience and does not feel the loss in so small a detail." He concluded that these "high rates of interest are not only permitted but are in a way useful and necessary." Cantillon suggested that if high rates on this type of loans are helpful rather than harmful, then why can't bankers make loans and charge high rates as well? Cantillon also made clear that the banker, or lender, is an entrepreneur, in that making loans risks losing both profit and capital when loans are not repaid. The banker, in effect, becomes an entrepreneur and must take some responsibility or face ruin.

In discussing these points, Cantillon attempted to exonerate the reputation of the lenderbanker. The banker is not a criminal, but someone who helps other entrepreneurs pursue profits. Just as with the case of the wholesaler of beer discussed above, if the risks are high, the implied rate of interest charged is high to compensate the wholesaler for potential defaults. Wholesalers do not deceive or defraud their customers, who are happy that products are readily available and at lower prices than if fewer retail entrepreneurs were in business. In the same manner, the business of making loans is not a matter of fraud, and when "regulated" by market forces all parties are generally better off. Ultimately, Cantillon concluded that bankers are "useful and necessary." However, they can be "ruined" if they extend loans much beyond their private capital. In any event, it is surely the case that bankers are entrepreneurs under Cantillon's definition of uncertainty bearer, that they provide valuable services, and are wellregulated in markets. Bankers lend money today, but are uncertain how much they will be repaid in the future, if anything.

\footnotetext{
${ }^{12}$ Cantillon (1755) discusses the business of banking in Part 3, Chapter 6 and elsewhere. At the time, money consisted of gold, silver, and banknotes, issued by banks to depositors. Most banking was fractional reserve banking. The particular fraction of a particular bank's policy was dependent on the type of bank it was and that was dependent on the needs of the bank's depositors. He recognized this as increasing the "circulation" of money as a positive and the possibility of bankruptcy as the negative. For a modern and detailed treatment of banking of this era see Hoffman, Postal-Vinay, and Rosenthal (2000).
} 


\section{Cantillon in a Bubble}

Cantillon's firsthand experience could have made clear to him that government contractors are categorically different than market entrepreneurs. This experience was strongly reinforced by John Law, the director of the Mississippi Company and the creator of the Mississippi Bubble. Cantillon was a private banker when John Law hired him in the fall of 1718. Law already had two of the most important French economists of the time working for him, Jean Francois Melon and $\mathrm{Du}$ Tot. However, Cantillon must have impressed Law because they formed a company with Joseph Gage to establish a settlement in Louisiana. Within a year's time Cantillon had made a fortune, lost confidence in Law's system, and left for England. Murphy concluded that Cantillon's departure resulted from his concerns over Law's system:

We believe that it was Cantillon's distrust of what was happening rather than a breakdown in his relationship with Law that was the crucial factor in his decision to leave France in August of 1719. If he had just been involved in a quarrel with Law he would not have recommended his friend the Duke of Chandos (a.k.a. James Brydges) to refrain from investing in the Mississippi System. (MURPHY, 1986, p. 79)

Cantillon extended his fortune by short selling Mississippi shares and correctly anticipating the results of John Law's exchange-rate manipulations.

It is also clear that Cantillon considered the Mississippi and South Sea companies and their bubbles to be both unstable enterprises and scams. They were attempts to transfer the national debt into shares of the companies with the assistance of monetary manipulation. Cantillon revealed his understanding of these bubbles in the very last paragraph of his Essai:

It is then undoubted that a bank with the complicity of a minister is able to raise and support the price of a public stock and to lower the rate of interest in the state at the pleasure of this minister when the steps are taken discreetly, and thus pay off the state debt. But these refinements which open the door to making large fortunes are rarely carried out for the sole advantage of the state, and those who take part in them are generally corrupted. The excess banknotes, made and issued on these occasions, do not upset the circulation, because being used for the buying and selling of stock they do not serve for household expenses and are not changed into silver. But if some panic or unforeseen crisis drove the holders to demand silver from the bank the bomb would burst and it would be seen that these are dangerous operations. (CANTILLON, 1755, s/p)

Cantillon generally restricted himself to positive economics throughout the Essai, but in the end he chose to speak frankly to his readers and to reveal that a national bank (i.e., central bank) is both unnecessary, a source of corruption and can create a grand disruption in the economy.

Cantillon started his career in the paymaster general's office, where great sums were spent and stolen, and this spending helped build up a large national debt in England during the War of Spanish Succession. He essentially ended his career working for John Law, who attempted to redeem the large national debt of France, that also resulted from the war, with company stock and paper money.

Hoffman, Postel-Vinay, and Rosenthal (2000 p. 69-72) show that the burden of government debt would eventually help ignite the French Revolution, and they label the Mississippi Bubble 
"the harshest default that France would witness until 1797." In both the case of building up the debt and of defaulting on it, private interests were working with government.

To be sure, there was risk, but it was the risk of being exposed and punished, not of losing capital and profits. There were also profits, but profits made largely on the basis of insider information and corrupt practices. Cantillon obviously saw that the profits garnered by such government contractors came at the expense of the general public, while the profits of market entrepreneurs actually benefit the general public. Therefore, it is logical to see why Cantillon associated the "entrepreneur" with market participants, operating under uncertainty to "regulate" the economy. Whereas, it is equally logical to see why Cantillon depicted government contractors, not as entrepreneurs, but as a type of dangerous social parasite who likely would weaken the economy, if not send it into chaos. Cantillon's experiences as a cause for his new theory of entrepreneurship is necessarily speculative, but is highly suggestive.

\section{Conclusion}

Richard Cantillon rejected the then-accepted meaning of the entrepreneur as government contractor who had fixed revenue, but unfixed costs. He changed this traditional definition to someone who bought inputs at fixed prices and sold goods at uncertain future market prices and was thus subject to uncertainty, profits and losses, and competition. This new entrepreneur would be the dependable force that regulated the market economy and allowed for the creation of economic theory, which in turn, shows us that the market is a self-regulating system of freedom, exchange and competition.

Cantillon's experiences as a government contractor and private business person are also explored here for clues to explain this transformation. Cantillon used his theoretical construct of the entrepreneur, who performed a core function in his system of economic theory with the aim of explaining the real world. Based on this analysis, we argue that Cantillon should be credited with the core modern meaning of entrepreneurship as the undertaking of ventures of exchange that occur under uncertainty guided by the prospect of profits and losses. The combination of theoretical necessity and his extensive career experience as both types of entrepreneur provides a plausible and credible explanation why he radically changed the meaning of the entrepreneur.

\section{References}

BÉLIDOR, Bernard F. La Science des ingénieurs Dans la Conduite des Travaux de Fortification et d'architecture Civile. Paris, 1729.

BROWN, Christopher; THORTON, Mark. How Entrepreneurship Theory Created Economic Theory. Quarterly Journal of Austrian Economics, v. 16, n. (Winter), p. 401-420, 2013.

CANTILLON, Richard. Essai sur la Nature du Commerce en Général. Auburn: Ludwig von Mises Institute, 2010 [1755].

EKELUND, Robert B. Jr.; HÉBERT, Robert; THORTON, Mark. Richard Cantillon: Anti-Mercantilism and the French Revolution. Working Paper. Ludwig von Mises Institute, 2019. 
GUPTA, Sanjeev; DE MELLO, Luiz; SHARAN, Raju. Corruption and Military Spending. European Journal of Political Economy, v. 17 (November), p. 749-777, 2001.

HAITZ, Louis. The Liberal Tradition in America: An Interpretation of American Political Though Since the Revolution. New York: Harcourt \& Inc, 1955.

HÉBERT, Robert F; LINK, Albert. The Entrepreneur: Mainstream Views and Radical Critiques. New York: Praeger Publishers, 1982.

HOFFMAN, P. T.; POSTEL-VINAY, J. L; ROSENTHAL, J. L. Priceless Markets, the Political Economy of Credit in Paris, 1660-1870. Chicago: University of Chicago Press, 2000.

HOSELITZ, Bert F. The Early History of Entrepreneurial Theory. Explorations in Entrepreneurial History, v. 3, p. 193-220, 1951.

JOHNSON, Ronald. N.; LIBECAP, Gary D. 1982. Contracting Problems and Regulation: The Case of the Fishery. The American Economic Review, v. 72, n. 5 (December.), p. 1005-1022, 1982.

LEONARD, Thomas. Illiberal Reformers: Race, Eugenics \& American Economics in the Progressive Era. Princeton University Press, 2016.

MURPHY, Antoin. Richard Cantillon: Entrepreneur and Economist. Oxford: Clarendon, 1986.

THORNTON, Mark. Richard Cantillon and the Origins of Economic Theory. Journal des Economistes et des Etudes Humaine, v. 8, n. 1 (March), p. 61-74, 1998.

THORNTON, Mark. Richard Cantillon and the Discovery of Opportunity Cost. History of Political Economy, v. 39, n. 1 (Spring), p. 97-119, 2007a.

THORNTON, Mark. Cantillon, Hume and the Rise of Anti-Mercantilism. History of Political Economy, v. 39 n. 3 (Fall), p. 453-480, 2007b.

THORNTON, Mark. Was Richard Cantillon a Mercantilist?. Journal of the History of Economic Thought, v. 29, n. 4 (December), p. 417-435, 2007c.

THORNTON, Mark. Cantillon and the Invisible Hand. Quarterly Journal of Austrian Economics, v. 12, n. 2, p. 27-46, 2009a.

THORNTON, Mark. Cantillon and the Rise of Anti-Mercantilism: Procesos de Mercado. Revista Europea de Economia Politica, v. 6, n. 1 (Spring) p. 13-42, 2009b.

THORNTON, Mark. Review Essay: Phishing for Phools: The Economics of Manipulation and Deception by George A. Akerlof and Robert J. Shiller. Quarterly Journal of Austrian Economics, v. 19, n. 1 (Spring), p. 85-100, 2016.

THORNTON, Mark. Turning the Word Upside Down: How Cantillon Redefined the Entrepreneur. Working Paper: Ludwig von Mises Institute, 2019.

RECEIVED DATE: JUN 282019

ACCEPTED DATE: AUG 152019 